\title{
Applicability of Pressure Retarded Osmosis Power Generation Technology in Istanbul
}

\author{
${ }^{1,2}$ Mehmet Emin PASAOGLU, ${ }^{1,2}$ Ismail KOYUNCU*,${ }^{2,4}$ Reyhan SENGUR-TASDEMIR, ${ }^{1,2}$ Serkan GUCLU, \\ ${ }^{1,2}$ Turker TURKEN, ${ }^{3}$ Bilge BUDEYRI, ${ }^{3}$ Orhan BAYKAN, ${ }^{3}$ Filiz DASKIRAN and ${ }^{3}$ Elif TEZCAN \\ ${ }^{1}$ Istanbul Technical University, Environmental Engineering Department, Maslak/Istanbul/Turkey \\ ${ }^{2}$ National Research Center on Membrane Technologies (MEM-TEK), Advanced Technology Center, Maslak/Istanbul/Turkey \\ 3 Istanbul Water and Sewerage Administration (İSKİ), Research \& Development Department, Eyup/Istanbul/Turkey \\ ${ }^{4}$ Istanbul Technical University, Nanoscience and Nanoengineering Department, Maslak/Istanbul/Turkey
}

\section{Article Info}

Article history:

Received Oct 19, 2018

Revised Nov 24, 2018

Accepted Nov 24, 2018

\section{Keyword:}

Osmotic Power

Pressure Retaded Osmosis

Membrane

Electricity Generation

Salinity Gradient Energy

\begin{abstract}
In this study, the applicability of pressure retarded osmosis power generation was investigated in order to meet the electricity demand in Turkey. Pressure retarded osmosis (PRO) is a method that converting salinity gradients to power using a semi-permeable membrane against an applied pressure and PRO is one of the promising candidates to reduce fossil fuel dependency. In PRO, water is transported from a low concentrated feed solution to a highconcentrated draw solution. According to the literature findings, in order to produce $1 \mathrm{MW}$ of electricity $1 \mathrm{~m}^{3} / \mathrm{s}$ fresh water flow is needed. Turkey is surrounded on three sides by water and has a big potential to develop this technology. Riva River is investigated in the scope this study. Currently Turkey's total installed power capacity reached $85.200 \mathrm{MW}$ at the end of 2017.Calculations of PRO power generation reveals that it is possible to generate $25,45 \mathrm{MW}$, If using $5 \%$ of total river flow.
\end{abstract}

\section{Corresponding Author:}

Prof. Dr. Ismail Koyuncu

Department of Environmental Engineering,

Istanbul Technical University,

Ayazaga Campus, Civil Engineering Faculty, Sariyer/Turkey

Email: koyuncu@itu.edu.tr

\section{Introduction}

Global energy consumption mainly depending on fossil fuels which are resulting an increase of climate change. In order to meet increasing energy resources, renewable energy sources such as solar, wind and tidal, biomass and geothermal sources have been introduced and take a share approximately $22 \%$ of the total global energy supply. Turkey's energy import dependency mainly based on oil and natural gas. Currently, only $26 \%$ of its total energy demand from its own domestic resources. Between OECD countries, Turkey has the highest rate of growing energy demand over the last 15 years. Figure 1 shows the electric energy demand increase in Turkey. Turkey's total electricity (power) demand has been increasing rapidly and it reached $264 \mathrm{TWh}$ in 2015. Ministry of Energy and Natural Resources expected to reach 416 TWh energy demand in 2023 for Turkey. Currently, primary energy demand is met by natural gas (35\%), coal (28.5\%), oil (27\%), hydro (7\%) and other renewables $(2.5 \%)$.

Electricity generation in 2015 accounted $37.8 \%$ of total electricity by natural gas. Other energy sources type for electricity generation in 2015 is shown in Figure 2. 


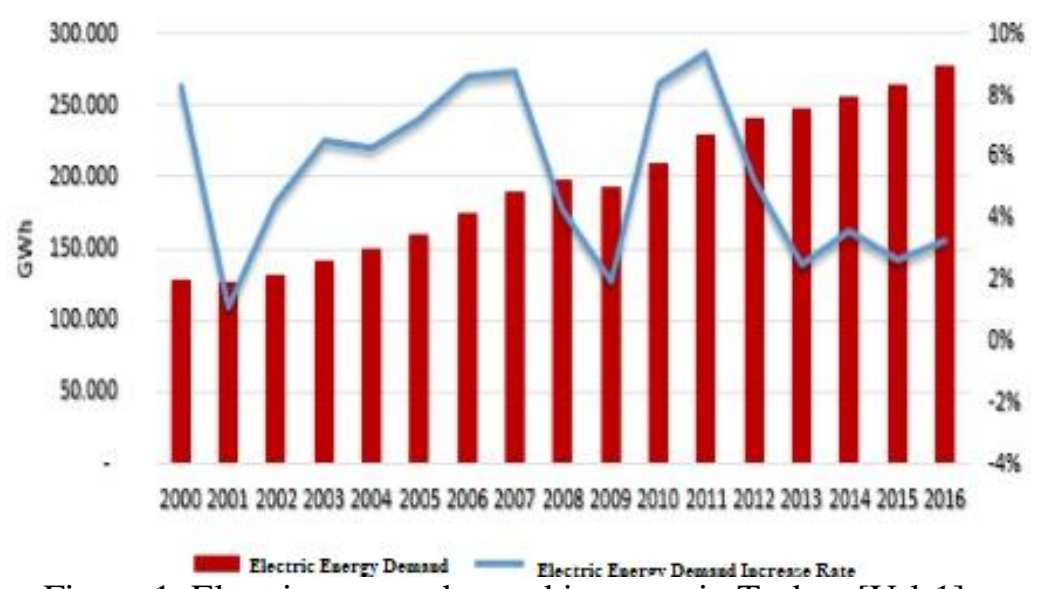

Figure 1. Electric energy demand increase in Turkey [Url-1].

According to the Energy and Natural Resources Ministry data Turkey added 5.840 MW of new electricity production in 2017 with $\$ 6.2$ billion total investments. With this newly added electricity generation Turkey's total installed power capacity reached 85.200 MW at the end of 2017 [Url-3]. When we investigated Turkey's renewable energy potential from wind energy plant, It is calculated with the assumption that 5MW power plant can be installed with $50 \mathrm{~m}$ altitude and wind speeds above $7.5 \mathrm{~m} / \mathrm{s}$ with the General Directorate of Renewable Energy (YEGM). The total installed capacity corresponds to $1.3 \%$ of the total area of the country and the total installed capacity is $48 \mathrm{GW}$ [1],[2]. Turkey's solar energy potential of $308 \mathrm{cal} / \mathrm{cm}^{2}$-day or 3.6 $\mathrm{kWh} / \mathrm{m}^{2}$-day that it is admissible. The average daily sunshine duration is 7.2 hours. All regions except the Black Sea Region, especially the Southeastern Anatolia and the Mediterranean regions, can be invested in solar energy potential [1],[3],[4]. Although the difference between these values is considered in Turkey sunbelt regions. Studies have found, for the sun to Turkey 376 TW is a power supply was estimated the value of the country's total installed capacity is as high as 500 times [1]. The distribution of geothermal resources varies considerably between countries and regions within the country. At the end of 2016, the geothermal power plant installed in the world for electric energy production is $13.3 \mathrm{GW}$. This installed power produces about $75 \mathrm{TWh}$ of electricity per year. Due to characteristics of the Alpine-Himalayan belt on Turkey which is a country with high geothermal potential. The geothermal potential of Turkey is theoretically $31.5 \mathrm{GW}$ [1], [Url-4]. Istanbul (Asian Side) has 2 electricity power plants. Istanbul (Asian Side) total production capacity is 25.1 MW and this energy depends on natural gas [Url-6]. Riva River, also known as Çayağzı Stream, is a stream located in the Kocaeli Peninsula, north of the Marmara Region. It is born near the Tepecik village of Gebze district of Kocaeli province and enters into the borders of Istanbul province. It passes through Pendik and Çekmeköy districts and flows into the Black Sea in the Beykoz district. The river forms the Ömerli Dam Lake in the Pendik district of Istanbul. This dam covers $48 \%$ of the drinking water requirement of the Istanbul province. The water is collected from the $38 \mathrm{~km}$ long section of the river with a total length of $70 \mathrm{~km}$. After Ömerli Dam Lake, Koçullu, Ömerli, Sırapınar, Hüseyinli, Bozhane, Öğümce, Göllü and Paşamandıra villages reach the Riva where they turn into the sea. This second part of the stream is covered with $75-80 \%$ of forests. The rest of the land is farmland and grassland [Url-7].

Another important renewable energy is Salinity Gradient Energy (SGE) which utilizes chemical potential difference between two solutions having different salinities. When $1 \mathrm{~m}^{3}$ of fresh water and seawater mixed, approximately $0.61 \mathrm{kWh}$ of free energy can be harvested [5]. It might be possible that global energy consumption demands meet with the potential of SGE with a value of $\sim 2.6 \mathrm{TW}$ [6].There are other factors that make this technology put forward such as less dependence of weather and seasonal conditions, no emissions of greenhouse gases. Nowadays, rapid population grown and insufficient water supply need an urgent and important challenge to develop equal access to water and social needs [17].

SGE has different types in practice, one of the most important on is Pressure-retarded osmosis (PRO). In PRO, using a semi-permeable membrane, water is transported from the feed to the draw side and generate power with the help of volumetric water flow operates a hydro-turbine [7]. In early stages reverse osmosis (RO) membranes were used. But, RO membranes were found unsuitable for PRO applications because of severe concentration polarization [7], [8]. 


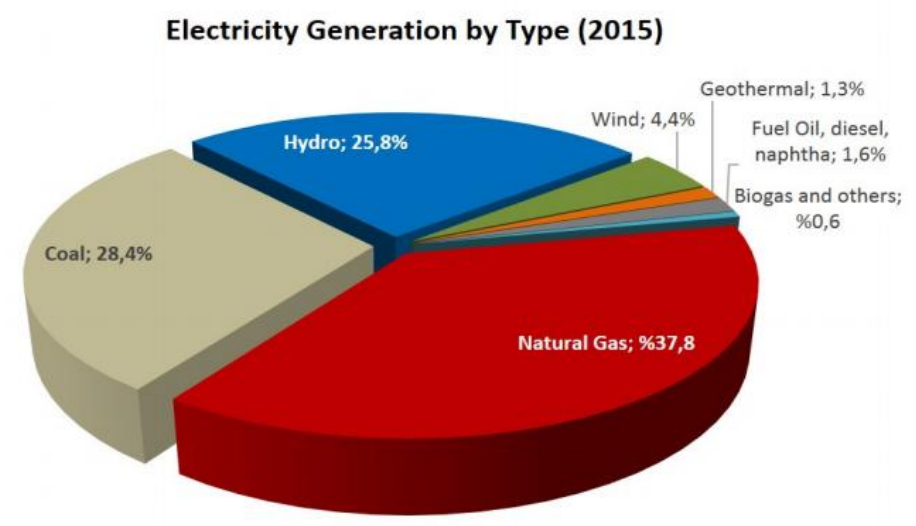

Source: MENR

Figure 2. Electricity generation by type in Turkey [Url-2].

\section{Material and methods}

\subsection{Theory of osmosis process}

Osmosis known as transportation of water from a dilute side to concentrated side through a membrane [9].Solution concentration in concentrated area decreases when the water flow came into the concentrated side. This water flow creates tendency through membrane which is expressed as osmotic pressure $\Delta \pi$ [10]. In Figure 3 a schematic drawing of pressure retarded osmosis is shown. According to Van't Hoffs law, osmotic pressure can be calculated.

$$
\Delta \pi=\frac{\text { Z.C.R.T }}{\mathrm{M}_{w}}
$$

Z: Valance, C: Concentrarion $\left(\mathrm{kg} / \mathrm{m}^{3}\right), \mathrm{R}$ : Universal gas constant $(\mathrm{J} / \mathrm{K} \cdot \mathrm{mol})$, T: Temperature $(\mathrm{K}), \mathrm{M}_{\mathrm{w}}$ : Molecular weight $(\mathrm{kg} / \mathrm{mol})$. The concentration profile of salt through the membrane is shown in Figure 4 . Osmotic pressure difference across the membrane severely affected by concentration polarization [11].

$\mathbf{t}=\mathbf{0}$

(Initial, C1>C2)

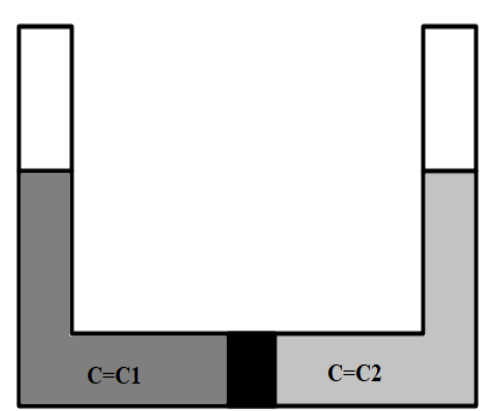

$\mathbf{t}=\mathbf{t} 1$

(Osmosis)

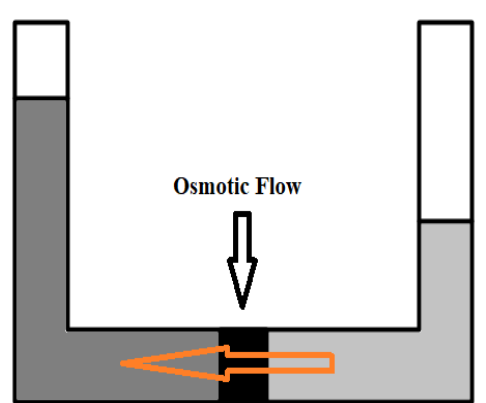

$\mathrm{t}=\mathrm{t} 2$

(Equilibrium)

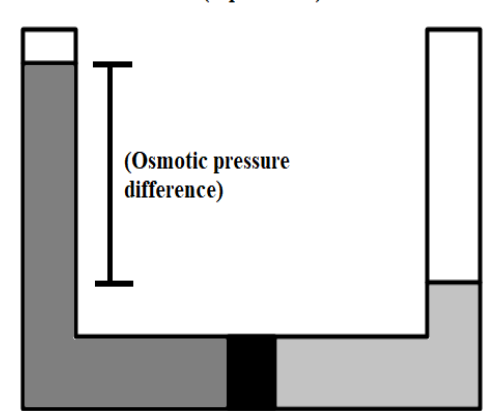

Figure 3. Schematic drawing of pressure retarded osmosis [11].

\subsection{Salinity power}

Power can be harvested from the pressure during osmosis. Literature studies show that a fixed volume of saltwater tank the theoretical approximation of pressure increment will be 26 bars which is equal to 270 meter high water column [12]. 
$\Delta \mathrm{P}<\Delta \pi$ pressure can be described as follows for complete rejection.

$$
\mathrm{J}_{\mathrm{v}}=\mathrm{A}(\Delta \pi-\Delta \mathrm{P})
$$

$\mathrm{J}_{\mathrm{v}}$ : Water flux and A is the permeability coefficient of the membrane.

The power describes as $\mathrm{E}$ (Watt or $\mathrm{J} / \mathrm{s}$ ) per unit membrane area is given by the product of flux and pressure difference.

$$
\begin{gathered}
\mathrm{E}=\mathrm{J}_{\mathrm{v}} \cdot \Delta \mathrm{P} \\
\mathrm{E}=\mathrm{A}(\Delta \pi-\Delta \mathrm{P}) \cdot \Delta \mathrm{P}
\end{gathered}
$$

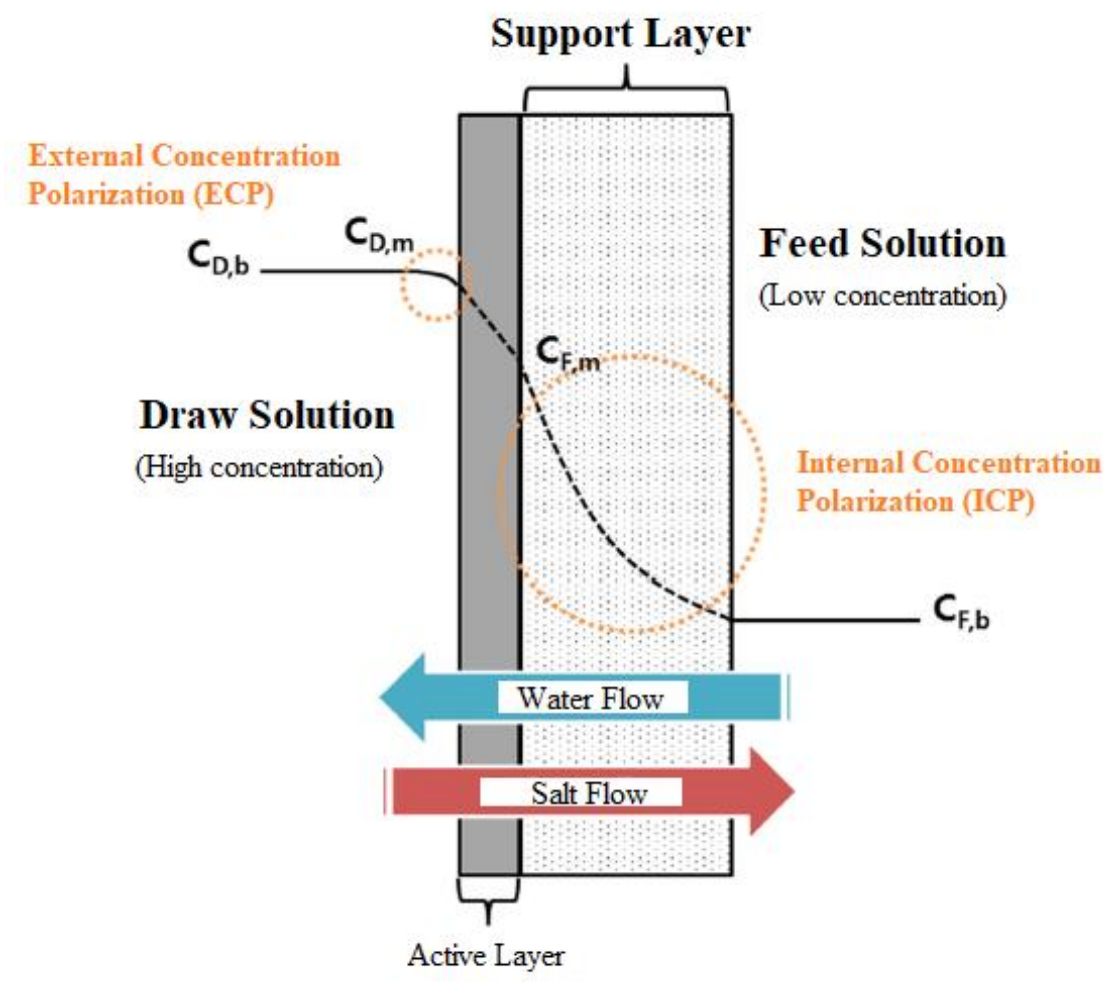

Figure 4. Concentration polarization and reverse salt flux flow in Pressure Retarded Osmosis (PRO). $C_{D, b}$ and $C_{F, b}$ draw solution and feed solution concentration respectively. $C_{D, m}$ shows concentration on active layer and $C_{F, m}$ shows concentration between active layer and support layer [7].

Differentiating Eq. 4 with over $\Delta \mathrm{P}$, gives the rate of change of energy with respect to $\Delta \mathrm{P}$. The maximum power $\left(\mathrm{W} / \mathrm{m}^{2}\right)$ can be harvested when the pressure is at a value of the osmotic pressure.

$$
\Delta \mathrm{P}=0.5 \pi
$$

Thus maximum power can be generated is

$$
\mathrm{E}_{\max }=0.25 . \mathrm{A} . \pi^{2}
$$

This equation shows that higher the gradient between salinity in the freshwater and saltwater higher pressure can be obtained from the system [13]. Practically, in a hydropower plant a water head of 100 to 145 meters equivalent 10 to 15 bars range [14]. According to the theory that $1 \mathrm{~m}^{3} / \mathrm{s}$ flow stream may able to produce $1 \mathrm{MW}$ of electricity power [15]. Increasing the fresh water flow rate can lead to increase power generation. Another important parameter is power density. In order to say pressure retarded osmosis process economically feasible 
4-6 $\mathrm{W} / \mathrm{m}^{2}$ power density is needed [11].

\subsection{PRO process}

River and sea water are fed into the plant after pretreatment in order to prevent fouling the membranes depending on the water quality. Figure 5 present a schematic of pressure retarded osmosis power plant.

Pressure retarded osmosis modules have different types such as hollow fiber or spiral wound. Low salt gradient water is transferred by membrane into the salty water side with $80-90 \%$ ratio. $5 \mathrm{~W} / \mathrm{m}^{2}$ power density have to be harvested in order to PRO economically viable. Pressure exchanger is another important objective which gives opportunity to use recycled energy by brackish water in order to enhance the pressure of salty water side.

Before planning to construct an economically viable PRO plant some important factors must be taking into account such as:

- The amount of water in the river,

- Qualities of fresh and sea water,

- Characteristics of the membranes and

- Physical and chemical conditions in the estuary [11].

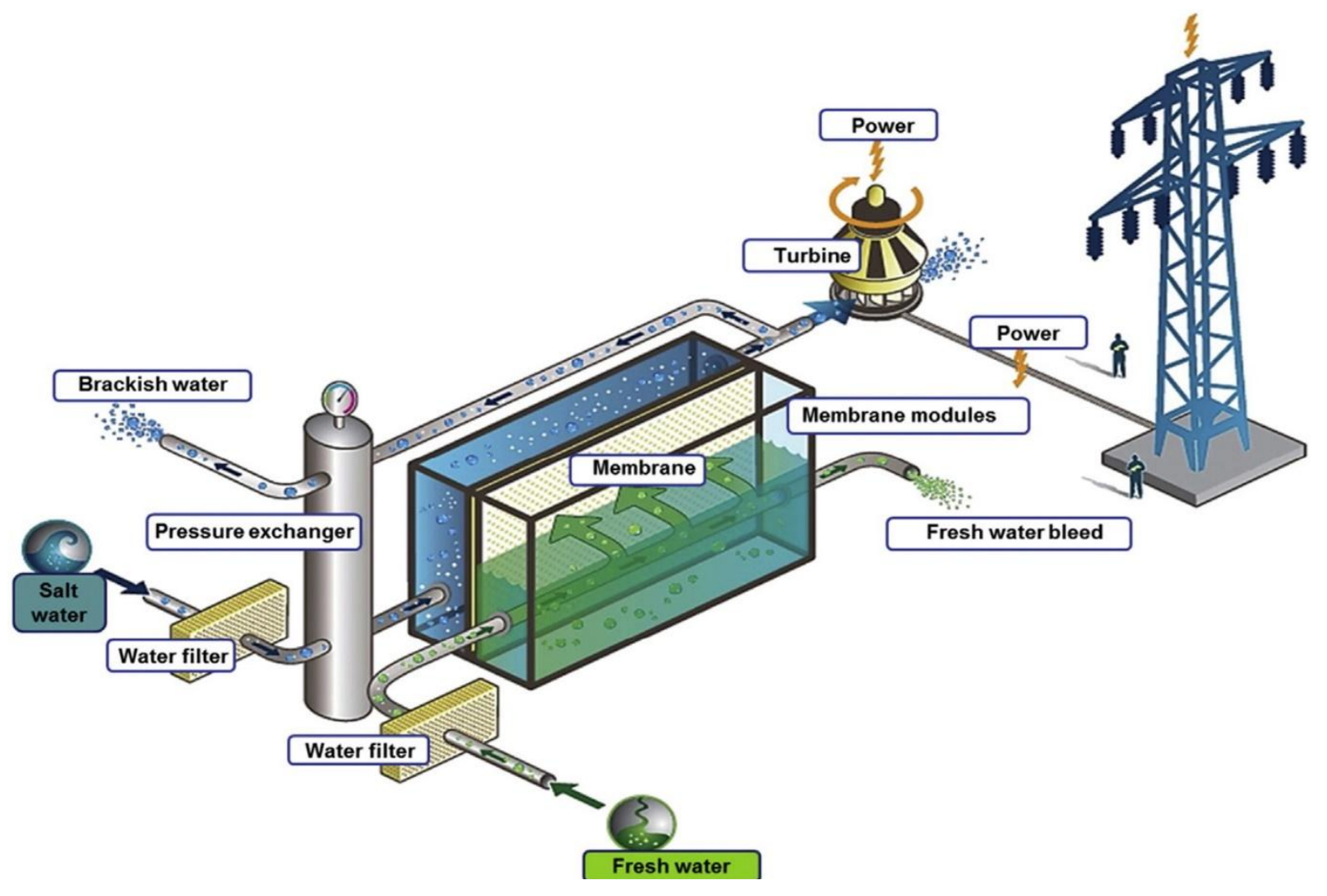

Figure 5. Seawater-river water PRO process for electricity production, adopted by Statkraft [16].

\subsection{Methodology}

Flow rates $\left(\mathrm{m}^{3} / \mathrm{s}\right)$ of selected river in Turkey is given in Table 1. Power generation calculated for Riva River under $5 \%, 10 \%, 15 \%$, and $20 \%$ of inlet water flow rate of river basin. 


\section{Results}

Electricity generation of selected river basins was calculated according to Eq.7. The power which could be extracted by PRO process under 5\% flow rate is shown in Table 1.

$$
\text { Power }(\mathrm{P})=\text { Power per Unit Volume }\left(\mathrm{W} / \mathrm{m}^{2}\right) \times \text { Flow rate }\left(\mathrm{m}^{3}\right)
$$

According to the electricity power calculation, results reveal that 25.45 MW could be harvested from Riva River.

Table 1. Power extracted by PRO process using 5\% of river total water flow rate.

\begin{tabular}{ccc}
\hline River name & Flow rates $\left(\mathrm{m}^{3} / \mathrm{s}\right)[\mathrm{Url}-5]$ & Power $(\mathrm{MW})$ \\
\hline Riva & 509 & 25.45 \\
\hline
\end{tabular}

Table 2. Power generation with the increasing of percentage of river flow for the PRO process

\begin{tabular}{cc}
\hline $\begin{array}{c}\text { Percentage of water used } \\
\text { for PRO process }(\%)\end{array}$ & $\begin{array}{c}\text { Power generated by PRO } \\
\text { process (MW) }\end{array}$ \\
\hline 5 & 25.45 \\
10 & 50.90 \\
15 & 76.35 \\
20 & 101.80 \\
\hline
\end{tabular}

\section{Conclusions}

In this study it is found that Istanbul is a rich city in terms of water streams for applying PRO power generation and it can support other renewable resources with a minimum power of $25.45 \mathrm{MW}$. According to the calculations for the selected river basin if $20 \%$ of total river flow used $101.80 \mathrm{MW}$ of electricity energy can be generated (Table 2). This number can be improved counting in other river basins and flow rates.

As a result, it is suggested that PRO process is a suitable green technology which can be practicable successfully in Istanbul. One of the major advantage of PRO process is ability to create reliable power supply with low environmental risks.

\section{References}

[1] Onat, N. (2018). Türkiye'de yenilenebilir kaynaklardan elektrik enerjisi üretimi: Mevcut durum ve gelecek beklentileri. Akıllı Ulaşım Sistemleri ve Uygulamaları Dergisi, 1 (1), 8-15. Retrieved from http://dergipark.gov.tr/jitsa/issue/35759/393554.

[2] Türkiye Rüzgâr Enerjisi Birliği, Rüzgâr Enerjisi ve Etkileşim Raporu, Kasım, 2016.

[3] Şen, Z. (2004).Türkiye'nin Temiz Enerji İmkânları, Mimar ve Mühendis Dergisi, Sayı: 33, Nisan MayısHaziran, 6-12.

[4] Varınca, K. B., Gönüllü, T., Türkiye'de Güneş Enerjisi Potansiyeli ve Bu Potansiyelin Kullanım Derecesi, Yöntemi ve Yaygınlığı Üzerine Bir Araştırma, UGHEK'2006: I. Ulusal Güneş ve Hidrojen Enerjisi Kongresi, ESOGÜ, Eskişehir, 21-23 Haziran 2006. 
[5] La Mantia, F.; Pasta, M.; Deshazer, H.D.; Logan, B.E.; Cui, Y. (2011). Batteries for efficient energy extraction from a water salinity difference. Nano Lett.,11, 1810-1813.

[6] Post, J.W.; Hamelers, H.V.; Buisman, C.J. (2008). Energy recovery from controlled mixing salt and fresh water with a reverse electrodialysis system. Environ. Sci. Technol.,42, 5785-5790.

[7] Kim, J., Jeoung K., Park, M.J., Shon, H.K., Kim, J.H. (2015). Recent Advances in Osmotic Energy Generation via Pressure-Retarded Osmosis (PRO) A Review, Energies, 8, 11821-11845.

[8] Lee, K.; Baker, R.; Lonsdale, H. (1981). Membranes for power generation by pressure-retarded osmosis. $J$. Membr. Sci.,8, 141-171.

[9] Achilli, A.; Cath, T.Y.; and Childress, A.E. (2009). Power generation with pressure retarded osmosis: An experimental and theoretical investigation. Journal of membrane science 343: 42-52.

[10] Rao, M. (2007). Reverse Osmosis. vol.12, No.5, pp.37-40.

[11] Karunarathne, H.D.S.S. and Walpalage, S. (2013). Applicability of Pressure Retarded Osmosis Power Generation Technology in Sri Lanka, 10th Eco-Energy and Materials Science and Engineering (EMSES2012), Energy Procedia 34, 211-217.

[12] Skilhagen, S.E. and Aaberg, R.J. (2006). Osmotic power power production based on the osmotic pressure difference between fresh water and sea water. Owemes. Citavecchia, Italy, 20-22 April.

[13] Skramesto, O.S., Skilhagen, S.E. and Nielsen, W.K. (2009). Power production based on osmotic pressure. Article; Waterpower XVI.

[14] Skilhagen, S.E., Dugstad, J.E. and Aaberg, R.J. (2007). Osmotic power-power production based on the osmotic pressure difference between waters with varying salt gradients. Desalination, 220:476-482.

[15] Jones, A.T. and Finley, W. (2003). In proceeding of Marine technology society OCEANS.

[16] Sarp, S., Li, Z., Saththasivam, J. (2016). Pressure Retarded Osmosis (PRO): Past experiences, current developments, and future prospects. Desalination 389, 2-14.

[17] Najifar, P., Kurtay, C. (2018). Harvesting Feasibility of Rain Water in Buildings. Periodicals of Engineering and Natural Sciences, 6 (1), 144-152.

[Url-1]: http://www.mfa.gov.tr/turkeys-energy-strategy.en.mfa, Accessed in May, 2018.

[Url-2]:http://www.mar7aba.com.tr/wpcontent/uploads/2017/03/sector_energy_blogshowcase_5.pdf Accessed in May, 2018.

[Url-3]:https://www.aa.com.tr/en/energy/general/turkey-adds-5-840-mw-of-power-capacity-in-2017/19143, Accessed in May, 2018.

[Url-4]: http://www.enerji.gov.tr/tr-TR/Sayfalar/Jeotermal, Accessed in Feb., 2017.

[Url-5]:http://www.dicle.edu.tr/a/skaradogan/DOKUMAN/Turkiyenin akarsulari vadileri.pdf, Accessed in May, 2018.

[Url-6]: http://www.emo.org.tr/ekler/64c47f97ee545d0 ek.pdf, Accessed in May, 2018.

[Url-7]: https://tr.wikipedia.org/wiki/Riva_Deresi, Accessed in May, 2018. 